\title{
High dose Erythropoietin increases Brain Tissue Oxygen Tension in Severe Vasospasm after Subarachnoid Hemorrhage
}

\author{
Raimund Helbok ${ }^{1 *}$, Ehab Shaker ${ }^{1,2}$, Ronny Beer ${ }^{1}$, Andreas Chemelli ${ }^{3}$, Martin Sojer ${ }^{1}$, Florian Sohm ${ }^{4}$, \\ Gregor Broessner ${ }^{1}$, Peter Lackner ${ }^{1}$, Monika Beck ${ }^{1}$, Alexandra Zangerle ${ }^{1}$, Bettina Pfausler ${ }^{1}$, Claudius Thome ${ }^{4}$ \\ and Erich Schmutzhard ${ }^{1}$
}

\begin{abstract}
Background: Vasospasm-related delayed cerebral ischemia (DCI) significantly impacts on outcome after aneurysmal subarachnoid hemorrhage $(\mathrm{SAH})$. Erythropoietin (EPO) may reduce the severity of cerebral vasospasm and improve outcome, however, underlying mechanisms are incompletely understood. In this study, the authors aimed to investigate the effect of EPO on cerebral metabolism and brain tissue oxygen tension $\left(\mathrm{P}_{\mathrm{b}} \mathrm{tO}_{2}\right)$.

Methods: Seven consecutive poor grade SAH patients with multimodal neuromonitoring (MM) received systemic EPO therapy (30.000 IU per day for 3 consecutive days) for severe cerebral vasospasm. Cerebral perfusion pressure (CPP), mean arterial blood pressure (MAP), intracranial pressure (ICP), $\mathrm{P}_{\mathrm{b}} \mathrm{tO}_{2}$ and brain metabolic changes were analyzed during the next 24 hours after each dose given. Statistical analysis was performed with a mixed effects model.

Results: A total of 22 interventions were analyzed. Median age was 47 years (32-68) and 86\% were female. Three patients (38\%) developed DCl. MAP decreased 2 hours after intervention $(P<0.04)$ without significantly affecting CPP and ICP. $\mathrm{P}_{\mathrm{b}} \mathrm{tO}_{2}$ significantly increased over time $(\mathrm{P}<0.05)$ to a maximum of $7 \pm 4 \mathrm{mmHg}$ increase 16 hours after infusion. Brain metabolic parameters did not change over time.
\end{abstract}

Conclusions: EPO increases $\mathrm{P}_{\mathrm{b}} \mathrm{tO}_{2}$ in poor grade $\mathrm{SAH}$ patients with severe cerebral vasospasm. The effect on outcome needs further investigation.

Keywords: Cerebral microdialysis, Erythropoietin, Multimodality monitoring, Subarachnoid hemorrhage

\section{Background}

Vasospasm-related delayed cerebral ischemia (DCI) is common and significantly impacts on outcome after aneurysmal subarachnoid hemorrhage (SAH). [1] Underlying mechanisms including inflammation, oxidative distress and apoptosis may lead to secondary brain tissue damage. [2] Strategies to prevent and treat cerebral vasospasm include hyperdynamic therapy and calcium channel blockers, however still remain suboptimal. [1] Other prophylactic agents such as endothelin A receptor antagonists were effective in experimental and animal

\footnotetext{
* Correspondence: raimund.helbok@uki.at

'Neurological Intensive Care Unit, Department of Neurology, Innsbruck Medical University, Innsbruck, Austria

Full list of author information is available at the end of the article
}

settings but failed to improve outcome in human trials [3-6]. There is some evidence that acute erythropoietin (EPO) treatment may reduce the severity of cerebral vasospasm and eventually improve outcome in SAH patients $[7,8]$. Underlying mechanisms extend far beyond erythropoiesis: EPO may enhance neurogenesis, decrease inflammation and inhibit apoptosis especially in the damaged brain where EPO receptors are highly expressed $[9,10]$. Timing of EPO treatment in the early phase of SAH may be crucial $[7,8]$, however, the acute effect of EPO on brain homeostasis in severe cerebral vasospasm has not been elucidated so far.

In this study we sought to describe the effect of EPO treatment on cerebral perfusion pressure (CPP), brain

\section{Biomed Central}


metabolism and brain tissue oxygen tension $\left(\mathrm{P}_{\mathrm{b}} \mathrm{tO}_{2}\right)$ in $\mathrm{SAH}$ patients with severe cerebral vasospasm.

\section{Methods}

\section{Patient selection and data collection}

Between April 2010 and March 2011 seven consecutive poor grade SAH patients with multimodal neuromonitoring (MM) receiving erythropoietin as compassionate treatment for severe cerebral vasospasm were studied. All patients were admitted to the Neurological Intensive Care Unit at Innsbruck Medical University. The clinical care for SAH patients conforms to guidelines set forth by the American Heart Association [1]. All patients received concomitant statin therapy and were on midazolame, sufentanil and/ or ketamine continuous infusions at the days of intervention. Severe vasospasm was defined by mean transcranial doppler (TCD) velocity $>180 \mathrm{~cm} / \mathrm{sec}$ and a Lindegaard ratio $>3$ when conventional treatment (continuous intravenous nimodipine application and hemodynamic augmentation with CPP target $>80 \mathrm{mmHg}$ ) failed. DCI was defined as appearance of new infarction on CT that was judged by an independent radiologist to be attributable to cerebral vasospasm.

\section{Intervention}

EPO (Epoetin alfa, Erypo ${ }^{\circledR}$, Janssen-Cilag Pharma, Vienna, Austria) $30.000 \mathrm{IU}$ diluted to $50 \mathrm{ml}$ of normal saline was administered as infusion over $30 \mathrm{~min}$ every day for 3 consecutive days immediately after severe vasospasm was diagnosed. The decision to start the intervention was made by the neurointensivist in charge (ES, BP, RB, RH). In one patient a single dose was given, another patient received two sets of interventions at intervals of 7 days, leading to 22 interventions analyzed.

\section{Neuromonitoring, data collection and ethical approval}

Based on the clinical and imaging criteria, the patient underwent monitoring of cerebral metabolism, brain tissue oxygenation (PbtO2), and ICP according to local institutional protocol which is in compliance with the Helsinki Declaration and has been approved by the local ethics committee (UN3898 285/4.8). Written informed consent was obtained according to federal regulations. Through a right frontal burr hole, a triple-lumen bolt was affixed to insert a Licox Clark-type probe (Integra Licox Brain Oxygen Monitoring, Integra NeuroSciences, Ratingen, Germany) to measure $\mathrm{PbtO} 2$ and an ICP parenchymal probe (NEUROVENT_P-TEMP, Raumedic, Münchberg, Germany). In addition, a high cut-off brain microdialysis catheter (CMA 71, Dipylon Medical, Solna, Sweden) was tunneled and inserted into the brain parenchyma for hourly assessment of brain metabolism. Isotonic perfusion fluid (Perfusion Fluid CNS, Dipylon Medical) was pumped through the system at a flow rate of $0.3 \mu \mathrm{l} / \mathrm{min}$. Hourly samples were analyzed with CMA 600 Microdialysis Analyzer (CMA/Microdialysis, Solna, Sweden) for cerebral extracellular glucose, pyruvate, and lactate concentrations. At least $1 \mathrm{~h}$ passed after the insertion of the probe and the start of the sampling, to allow for normalization of changes due to probe insertion. The location of the monitoring catheters in the white matter of the right frontal lobe was confirmed by brain CT scan immediately after the procedure. All continuously measured parameters were saved on a 3 min average interval using our patient data management system (Centricity* Critical Care 7.0 SP2, GE Healthcare Information Technologies, Dornstadt, Germany). Transcranial Doppler sonography was performed using the DWL Doppler-Box system (Compumedics, Singen Germany). Data on CPP, ICP and MAP were available during all interventions, $\mathrm{P}_{\mathrm{b}} \mathrm{tO}_{2}$ and microdialysis in 14 and 18 observations, respectively.

\section{Statistic}

Continuous variables were assessed for normality. Normally distributed data were reported as mean and standard error of mean, nonparametric data as median and interquartile range (IQR), unless indicated otherwise. Categorical variables were reported as count and proportions in each group. Hourly recorded brain metabolic parameters were averaged for 6 hours episodes, and continuously recorded parameters $\left(\mathrm{P}_{\mathrm{b}} \mathrm{tO}_{2}, \mathrm{CPP}, \mathrm{MAP}, \mathrm{ICP}\right)$ for 2 hours episodes. Baseline values were calculated accordingly and changes from baseline were analyzed: multiple observations per subject were handled by using generalized estimating equations with an autoregressive working correlation matrix. For all tests, significance was set at $\mathrm{P}<0.05$. All analyses were performed with SPSS V19.0 (SPSS Inc., Chicago, Illinois).

\section{Results}

\section{General characteristics and outcome}

Baseline characteristics are described in the Table 1. Median patient age was 47 years (IQR:32-68) and six of seven were female. None of the patients had a history of malignancy or thrombembolism and no thromboembolic events occurred during hospitalization. All patients developed severe vasospasm in the anterior circulation of the aneurysm site and received Erythropoietin (EPO) at a median of 9 days (IQR:6-12) after ictus. None of the patients died during hospitalization and 3 patients (38\%) developed DCI with evidence of new cerebral infarctions at the site of the ruptured aneurysm distant $(>3 \mathrm{~cm})$ to the neuromonitoring probes. In these patients cranial CT scan had been performed after the observation period.

\section{Effect of erythropoietin on physiologic variables}

Baseline CPP and MAP were $86 \mathrm{mmHg}$ (IQR:77-95) and $99 \mathrm{mmHg}$ (IQR:85-105), respectively, and ICP was 
Table 1 Characteristics of EPO patient cohort

\begin{tabular}{|c|c|c|c|c|c|c|c|c|c|}
\hline Patients & Age & Sex & $\begin{array}{c}\text { Admission } \\
\text { H\&H }\end{array}$ & $\begin{array}{l}\text { Modified } \\
\text { Fisher }\end{array}$ & SAH sum-score & $\begin{array}{l}\text { IVH sum- } \\
\text { score }\end{array}$ & $\begin{array}{l}\text { Infarction on } \\
\text { admission CT }\end{array}$ & \multicolumn{2}{|c|}{ ICH on admission CT } \\
\hline 1 & 53 & $F$ & 4 & 3 & 15 & 1 & no & \multicolumn{2}{|r|}{ yes } \\
\hline $2 \mathrm{a}$ & 40 & $\mathrm{~F}$ & 5 & 1 & 12 & 0 & no & \multicolumn{2}{|r|}{ yes } \\
\hline $2 b$ & 40 & $\mathrm{~F}$ & 5 & 1 & 12 & 0 & no & \multicolumn{2}{|r|}{ yes } \\
\hline 3 & 69 & $\mathrm{~F}$ & 4 & 3 & 25 & 8 & no & \multicolumn{2}{|r|}{ no } \\
\hline 4 & 32 & $\mathrm{~F}$ & 5 & 4 & 18 & 3 & no & \multicolumn{2}{|r|}{ no } \\
\hline 5 & 29 & M & 5 & 4 & 14 & 4 & no & \multicolumn{2}{|r|}{ no } \\
\hline 6 & 68 & $\mathrm{~F}$ & 5 & 3 & 30 & 0 & no & \multicolumn{2}{|r|}{ no } \\
\hline \multirow[t]{10}{*}{7} & 47 & $\mathrm{~F}$ & 3 & 4 & 18 & 4 & no & \multicolumn{2}{|r|}{ no } \\
\hline & $\begin{array}{l}\text { Aneurysm } \\
\text { Location }\end{array}$ & $\begin{array}{l}\text { Monitoring } \\
\text { location }\end{array}$ & $\begin{array}{c}1=\text { coiling } \\
2=\text { clipping }\end{array}$ & $\begin{array}{c}\text { Admission } \\
\text { Glucose } \\
\text { (mg/dL) }\end{array}$ & $\begin{array}{c}\text { Admission SBP } \\
(\mathrm{mmHg})\end{array}$ & $\begin{array}{c}\text { Time to } \\
\text { Erythropiet } \\
\text { in treatment }\end{array}$ & $\begin{array}{l}\text { New infarction on } \\
\text { follow up CT }\end{array}$ & $\begin{array}{l}\text { CT- } \\
\text { vasospasm } \\
\text { related } \\
\text { ischemia } \\
\text { territory }\end{array}$ & $\begin{array}{c}\text { mRS at ICU } \\
\text { discharge }\end{array}$ \\
\hline & R MCA & R frontal & 2 & 154 & 230 & 8 & 1 & $\begin{array}{l}\text { R MCA,R } \\
\text { ACA }\end{array}$ & 5 \\
\hline & R MCA & R frontal & 2 & 217 & 101 & 2 & 1 & R MCA & 5 \\
\hline & R MCA & R frontal & 2 & 217 & 101 & 11 & 0 & 0 & 5 \\
\hline & PICA r & R frontal & 1 & 299 & 120 & 16 & 0 & 0 & 4 \\
\hline & R PCOA & R frontal & 1 & 154 & 144 & 12 & 0 & 0 & 3 \\
\hline & $\mathrm{ACOA}$ & R frontal & 1 & 96 & 144 & 9 & 0 & 0 & 2 \\
\hline & R MCA & R frontal & 2 & 213 & 115 & 9 & 0 & 0 & 3 \\
\hline & $\mathrm{ACOA}$ & R frontal & 1 & 184 & 120 & 6 & 1 & $\begin{array}{c}\text { L ACA, } \\
\text { R } \\
\text { MCA }\end{array}$ & 5 \\
\hline
\end{tabular}

$\mathrm{R}=$ right; $\mathrm{L}=$ left; $\mathrm{H} \& \mathrm{H}=$ Hunt-Hess Grade; $\mathrm{SAH}$ sum score grades the amount of blood in 10 basal cisterns and fissures $(0=$ no $\mathrm{SAH}, 1=\mathrm{small} \mathrm{SAH}, 2=\mathrm{moderate}$ $\mathrm{SAH}, 3$ = completely filled with SAH) by adding each of the 10 individual cistern scores (range 0-30); IVH sum score grades the amount of blood in the right and left lateral, third and fourth ventricle $(0=$ no blood, $1=$ sedimentation, $2=$ partly filled, $3=$ completely filled) by adding each of the 4 individual ventricle scores (range 0-12); $\mathrm{ACOA}=$ anterior communicating artery; $\mathrm{PCOA}=$ posterior communicating artery; $\mathrm{MCA}=$ middle cerebral artery; $\mathrm{SBP}=$ systolic blood pressure; $\mathrm{DCl}=$ delayed cerebral ischemia; $\mathrm{CT}=$ computed tomography; $\mathrm{SAH}=$ subarachnoidal hemorrhage; $\mathrm{ICH}=$ intracerebral hemorrhage; $\mathrm{IVH}=$ intraventricular hemorrhage; $\mathrm{mRS}=$ modified Rankin Scale.

within normal limits (7 mmHg, IQR:4-11). MAP decreased to $92 \mathrm{mmHg}$ (IQR:82-101) 2 hours after intervention $(\mathrm{P}<0.04)$ returning to baseline for the remaining 24 hours without significantly affecting CPP and ICP (Figure 1, Panel A-C).

\section{Effect of erythropoietin on brain tissue oxygen tension} and brain metabolism

$\mathrm{P}_{\mathrm{b}} \mathrm{tO}_{2}$ (baseline $29 \mathrm{mmHg}$, IQR:22-32) significantly increased over time by $4 \pm 3 \mathrm{mmHg}$ (mean increase compared to baseline) to a maximum of $7 \pm 4 \mathrm{mmHg}$ increase 16 hours after start of intervention $(\mathrm{P}<0.05)$ (Figure 1 , Panel D). All patients had an increase in $\mathrm{P}_{\mathrm{b}} \mathrm{tO}_{2}$ at a certain point during the follow up time of 24 hours. Accounting for the EPO dose given $\left(1^{\text {st }}, 2^{\text {nd }}, 3^{\text {rd }}\right)$ per patient did not affect the observed result. Hemoglobin (baseline $9.5 \mathrm{mg} /$ $\mathrm{dL}$, IQR:9-11.5), body temperature $\left(36.8^{\circ} \mathrm{C}\right.$, IQR: $36,6-$ 37.1) and SpO2 (96\%, IQR:95-97) remained stable and respirator settings were not changed during the 24 h-observation periods.
Baseline brain metabolic data showed an increased median LPR (32, IQR:29-38) and slightly decreased brain glucose (1.1 mmol/L, IQR:0.8-2.8). Median brain lactate and pyruvate was $4.6 \mathrm{mmol} / \mathrm{L}$ (IQR:2.4-6.1) and $131 \mu \mathrm{mol} / \mathrm{L}$ (IQR:88-158), respectively. There was no significant change in brain lactate, pyruvate and brain glucose during the observation periods (Figure 2, Panel A and B).

\section{Discussion}

Our findings suggest that high-dose systemic EPO treatment increases brain tissue oxygen tension in patients with severe vasospasm after SAH. The present data are of potential importance because they support the hypothesis of a beneficial effect of high-dose systemic EPO beyond erythropoeisis on human brain tissue.

Vasospasm occurs in up to $70 \%$ of aSAH patients, leads to decreased oxygen delivery with tissue hypoxemia, eventually resulting in brain tissue ischemia [1]. In in-vivo models of cerebral ischemia EPO and its receptor are highly expressed [11-13]. Experimental and clinical studies 

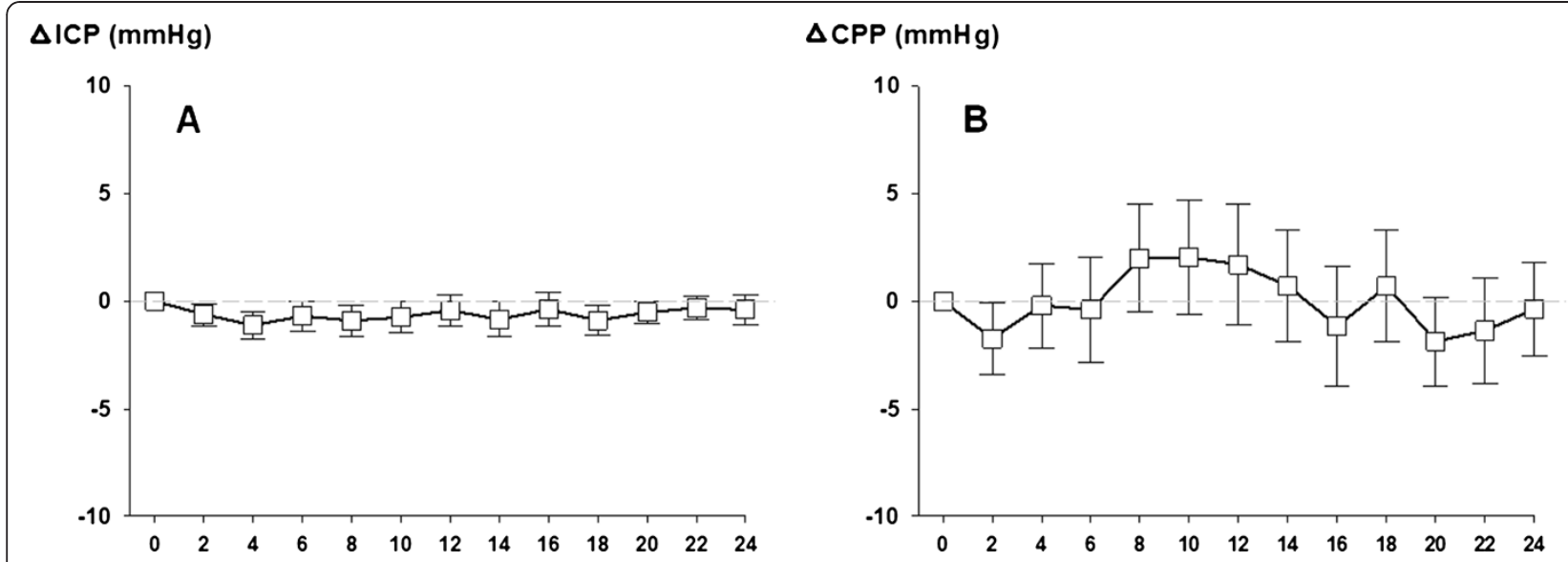

$\triangle M A P(\mathbf{m m H g})$

$\triangle \mathrm{PbtO} 2(\mathrm{mmHg})$
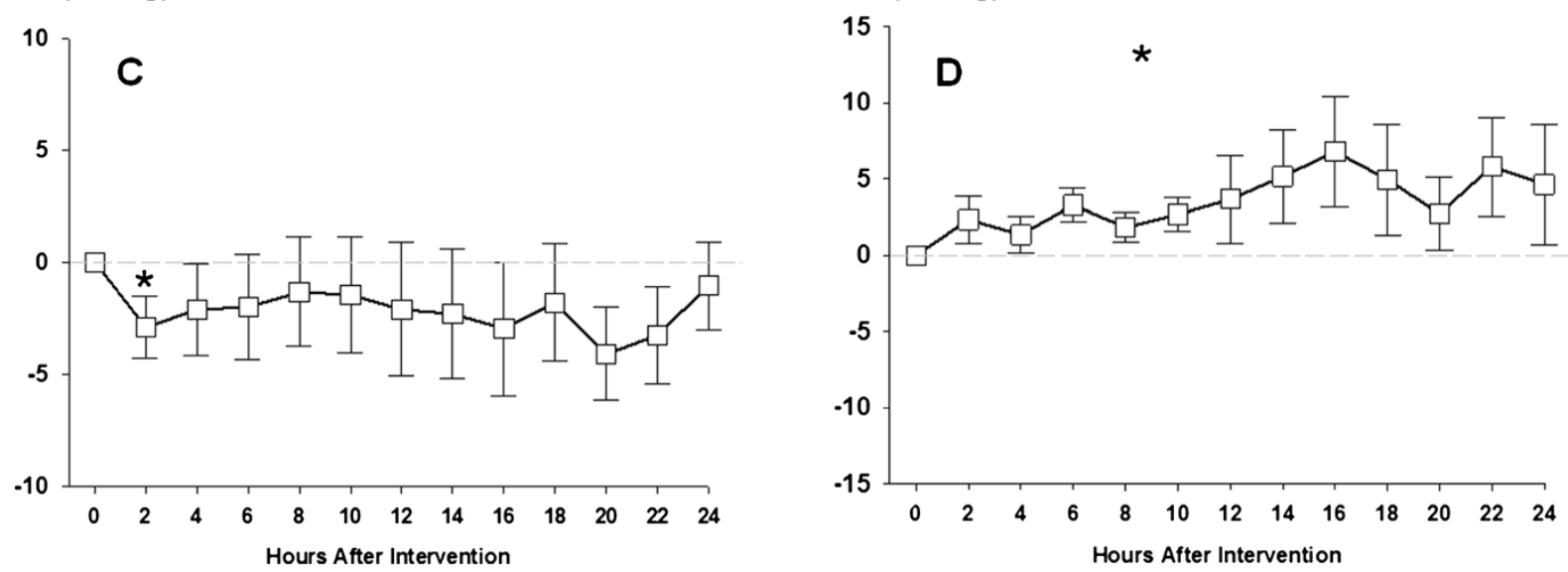

Figure 1 Two-hourly averaged changes in cerebral perfusion pressure (CPP), mean arterial pressure (MAP), intracranial pressure (ICP) and brain tissue oxygen tension (PbtO2) following EPO (30.000 IU over $30 \mathrm{~min}$ ) therapy, (mean $\pm \mathrm{SEM})$. ${ }^{*} P<0.05$

suggest a neuroprotective effect of EPO by decreasing inflammation, enhancing neurogenesis, inhibiting apoptosis and limiting $\mathrm{SAH}$-induced oxidative damage especially in vulnerated brain tissue $[9,10,14,15]$. The effect of EPO on brain tissue oxygen tension may be multifactorial as $\mathrm{P}_{\mathrm{b}} \mathrm{tO}_{2}$ is considered as marker of oxygen delivery, diffusion and consumption.

In an experimental model of ischemic tissue damage pretreatment with EPO improved microcirculation through increased arteriolar and venular blood flow with consecutive enhanced brain tissue oxygenation [16]. In this model, the beneficial effect of EPO was antagonized by blockade of NO synthase (NOS) activity, suggesting a link between EPO and NO-dependent vasodilatory effects [16], which has also been postulated in a rabbit SAH model of cerebral vasospasm $[17,18]$. After acute brain injury in humans, a strong correlation of $\mathrm{P}_{\mathrm{b}} \mathrm{tO}_{2}$ and cerebral blood flow may exist in certain circumstances [19]. This may explain our findings of $\mathrm{P}_{\mathrm{b}} \mathrm{tO}_{2}$-increase after EPO treatment, however, we did not measure cerebral blood flow in our patients to elaborate further on this finding. EPO may also enhance angiogenesis and thereby increase the amount of oxygen delivered to hypoxic tissue [20]. Proposed mechanisms include direct activation of endothelial cells by binding on the EPO-receptor or via activation of the vascular endothelial growth factor (VEGF)/VEGF receptor system [21]. In our patients, this hypothesis is unlikely as an increase in $\mathrm{P}_{\mathrm{b}} \mathrm{tO}_{2}$ was observed within hours.

Another potential mechanism how EPO may increase PbtO2 is through its anti-inflammatory potency [22]. In vivo attenuation of the inflammatory response was achieved by EPO pretreatment in critically ischemic tissue with a significant effect after 5 hours [16]. Reduced metabolic demand and therefore oxygen consumption may eventually result in increased brain tissue oxygen tension with a latency of a few hours. Although we have not analyzed brain extracellular parameters of inflammation in our patients, the observed $\mathrm{P}_{\mathrm{b}} \mathrm{tO}_{2}$ increase hours after EPO administration supports this hypothesis.

EPO did not improve brain metabolism, which replicates a previous study on 73 aSAH patients receiving 3 doses of EPO-alpha $500 \mathrm{IU} / \mathrm{kg} /$ day early after the initial 

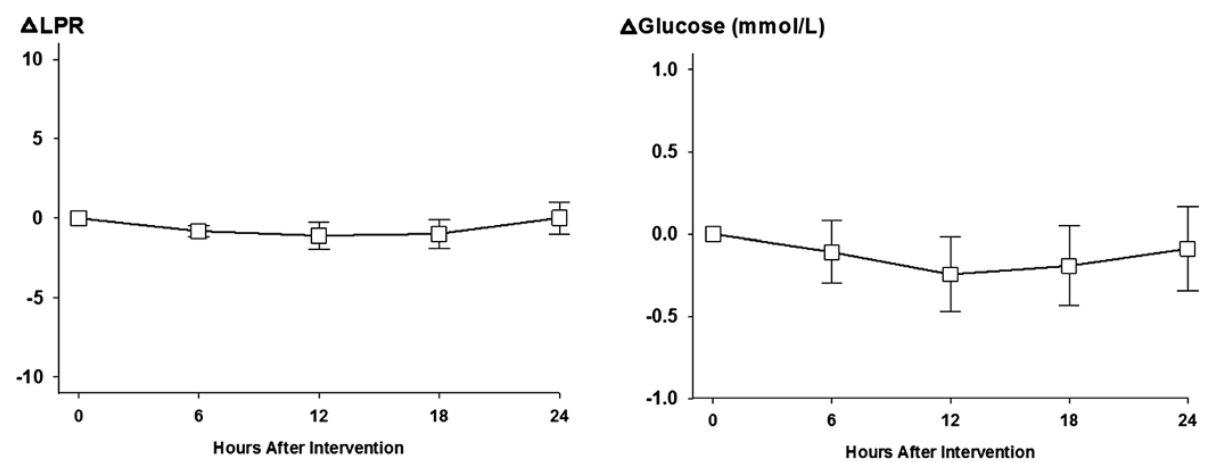

Figure 2 Six-hourly averaged change in lactat-pyruvate ratio (LPR) and brain tissue glucose concentration following EPO (30.000 IU over $30 \mathrm{~min}$ ) therapy, (mean $\pm \mathrm{SEM})$.

bleed [8]. The moderate derangement in brain metabolism at baseline in the absence of brain tissue hypoxia in our patients suggests that an increase in $\mathrm{PbtO} 2$ may not necessarily translate into improved brain metabolism. The effect of EPO on brain homeostasis in the setting of aSAH patients with vasospasm-related ischemic pattern of brain metabolic crisis (LPR $>40$ and Glucose $<0.7 \mathrm{mmol} / \mathrm{L}$ associated with $\mathrm{P}_{\mathrm{b}} \mathrm{tO}_{2}<20 \mathrm{mmHg}$ ) would be of upmost interest. However, it seems important that EPO treatment has to be initiated in a timely fashion before ischemic damage occurs [11]. Elevation of cerebral LPR may also be explained by brain mitochondrial dysfunction [23], and EPO restored brain mitochondrial function in an experimental TBI model and may enhance cellular energy generation [10].

We used EPO as compassionate treatment in patients with severe cerebral vasospasm after aSAH following an institutional protocol. We carefully explore patients on underlying malignant diseases or risk of thromboembolism to limit this potential side effect of EPO [24]. Like in a previous trial including $80 \mathrm{aSAH}$ patients, we used a high dose EPO regimen (total average dose of $90.000 \mathrm{IU}$ ) and did not observe any thromboembolic events [7].

Several limitations of the present study include a small sample size, a retrospective observational study design, a single institutional observation and lack of timed cranial CT scans. In addition, we did not routinely perform cerebral angiograms and the diagnosis of vasospasm was based on TCD studies. Therefore we want to emphasize, that in this pilot study we investigated the immediate physiologic response of high dose EPO on brain homeostasis in the setting of severe vasospasm. Moreover, we did not measure reticulocyte count in our patients, however hemoglobin and MAP remained stable after EPO treatment. Due to the small samples size a proper multivariate model could not be applied, however we did not observe changes in confounding factors of $\mathrm{P}_{\mathrm{b}} \mathrm{tO}_{2}$, e.g. respirator settings. The ruptured aneurysm was located in the posterior circulation in 2 patients and the monitoring probes were placed in the ispsilateral right frontal white matter. We rarely consider invasive monitoring of regions in the occipital lobe or posterior fossa. Because both patients had a high SAH sum score, admission global cerebral edema and developed generalized vasospasm, the apparently remote distance between the vascular territory of the aneurysm bearing vessel and monitoring probes is of minor significance.

In this pilot study we did not gather information on cerebrovascular autoregulation and tissue enzyme activation which might also play a role in the EPO-related increases in $\mathrm{P}_{\mathrm{b}} \mathrm{tO} \mathrm{O}_{2}$. Noteworthy, it has been shown that EPO can restore cerebral autoregulation after SAH $[7,25]$ leading to enhanced cerebral blood flow and oxygen delivery to the brain. Also, EPO has been demonstrated to attenuate ischemia induced apoptotic cell death by modulation of the caspase cascade and may therefore influence $\mathrm{P}_{\mathrm{b}} \mathrm{tO}_{2}[16]$.

\section{Conclusions}

These preliminary data suggest a beneficial effect of EPO in poor grade SAH patients with severe cerebral vasospasm. Further studies in larger cohorts are needed to evaluate the EPO effect on the long-term functional outcome of SAH patients.

\section{Competing interests}

The authors declare that they have no competing interests.

\section{Authors' contributions}

$\mathrm{RH}$ : concept, idea, analysis, writing, drafting, ES: writing, data collection. RB: idea, drafting, revising the manuscript. AC: angiogram, idea, drafting. MS: transcranial Doppler measurements, drafting. FS: insertion of multimodal neuromonitoring devices, drafting. GB: drafting. PL: drafting. MB: data collection. AZ: transcranial Doppler measurements, drafting. BP: idea, drafting. $C T$ : drafting, editing, revising the manuscript. ES: idea, drafting, revising the manuscript. All authors have given final approval of the current version of this manuscript.

\section{Acknowledgements}

We thank the attendings, fellows and nurses of the Neuroscience ICU for their overall support of this project. 


\section{Grant}

Ehab Shaker was supported by an Educational Fellowship granted by the European Federation of Neurological Societies

\section{Author details}

'Neurological Intensive Care Unit, Department of Neurology, Innsbruck Medical University, Innsbruck, Austria. ${ }^{2}$ Department of Neurology, Cairo University, Cairo, Egypt. ${ }^{3}$ Department of Radiology, Innsbruck Medical University, Innsbruck, Austria. ${ }^{4}$ Department of Neurosurgery, Innsbruck Medical University, Innsbruck, Austria.

Received: 28 November 2011 Accepted: 17 May 2012

Published: 6 June 2012

\section{References}

1. Bederson JB, Connolly ES Jr, Batjer HH, Dacey RG, Dion JE, Diringer MN, Duldner JE Jr, Harbaugh RE, Patel AB, Rosenwasser RH: Guidelines for the management of aneurysmal subarachnoid hemorrhage: a statement for healthcare professionals from a special writing group of the Stroke Council, American Heart Association. Stroke 2009, 40(3):994-1025.

2. Zhou Y, Martin RD, Zhang JH: Advances in experimental subarachnoid hemorrhage. Acta Neurochir Suppl 2011, 110(Pt 1):15-21.

3. Macdonald RL, Higashida RT, Keller E, Mayer SA, Molyneux A, Raabe A, Vajkoczy P, Wanke I, Bach D, Frey A, et al: Clazosentan, an endothelin receptor antagonist, in patients with aneurysmal subarachnoid haemorrhage undergoing surgical clipping: a randomised, double-blind, placebo-controlled phase 3 trial (CONSCIOUS-2). Lancet Neurol 2011, 10(7):618-625.

4. Hansen-Schwartz J, Vajkoczy P, Macdonald RL, Pluta RM, Zhang JH: Cerebral vasospasm: looking beyond vasoconstriction. Trends Pharmacol Sci 2007, 28(6):252-256.

5. Pluta RM: Delayed cerebral vasospasm and nitric oxide: review, new hypothesis, and proposed treatment. Pharmacol Ther 2005, 105(1):23-56

6. Ferro JM, Canhao P, Peralta R: Update on subarachnoid haemorrhage. J Neurol 2008, 255(4):465-479.

7. Tseng MY, Hutchinson PJ, Richards HK, Czosnyka M, Pickard JD, Erber WN, Brown S, Kirkpatrick PJ: Acute systemic erythropoietin therapy to reduce delayed ischemic deficits following aneurysmal subarachnoid hemorrhage: a Phase II randomized, double-blind, placebo-controlled trial. Clinical article. J Neurosurg 2009, 111(1):171-180.

8. Springborg JB, Moller C, Gideon P, Jorgensen OS, Juhler M, Olsen NV: Erythropoietin in patients with aneurysmal subarachnoid haemorrhage: a double blind randomised clinical trial. Acta Neurochir (Wien) 2007, 149:(11)1089-1101. discussion 1101.

9. Turner JD, Mammis A, Prestigiacomo CJ: Erythropoietin for the treatment of subarachnoid hemorrhage: a review. World Neurosurg 2010, 73(5):500-507.

10. Xiong Y, Chopp M, Lee CP: Erythropoietin improves brain mitochondrial function in rats after traumatic brain injury. Neurol Res 2009, 31(5):496-502.

11. Bernaudin M, Marti HH, Roussel S, Divoux D, Nouvelot A, Mackenzie ET, Petit E: A potential role for erythropoietin in focal permanent cerebral ischemia in mice. J Cereb Blood Flow Metab 1999, 19(6):643-651.

12. Sadamoto Y, Igase K, Sakanaka M, Sato K, Otsuka H, Sakaki S, Masuda S, Sasaki R: Erythropoietin prevents place navigation disability and cortical infarction in rats with permanent occlusion of the middle cerebral artery. Biochem Biophys Res Commun 1998, 253(1):26-32.

13. Marti HH: Erythropoietin and the hypoxic brain. J Exp Biol 2004, 207(Pt 18):3233-3242.

14. Maiese K, Chong ZZ, Hou J, Shang YC: Erythropoietin and oxidative stress. Curr Neurovasc Res 2008, 5(2):125-142.

15. Jerndal M, Forsberg K, Sena ES, Macleod MR, O'Collins VE, Linden T, Nilsson M, Howells DW: A systematic review and meta-analysis of erythropoietin in experimental stroke. J Cereb Blood Flow Metab 2010, 30(5):961-968.

16. Contaldo C, Elsherbiny A, Lindenblatt N, Plock JA, Trentz O, Giovanoli P, Menger MD, Wanner GA: Erythropoietin enhances oxygenation in critically perfused tissue through modulation of nitric oxide synthase. Shock 2009, 31(6):599-606.

17. Santhanam AV, Smith LA, Akiyama M, Rosales AG, Bailey KR, Katusic ZS: Role of endothelial NO synthase phosphorylation in cerebrovascular protective effect of recombinant erythropoietin during subarachnoid hemorrhage-induced cerebral vasospasm. Stroke 2005, 36(12):2731-2737.
18. Murphy AM, Xenocostas A, Pakkiri P, Lee TY: Hemodynamic effects of recombinant human erythropoietin on the central nervous system after subarachnoid hemorrhage: reduction of microcirculatory impairment and functional deficits in a rabbit model. J Neurosurg 2008, 109(6):1155-1164.

19. Jaeger M, Soehle M, Schuhmann MU, Winkler D, Meixensberger J: Correlation of continuously monitored regional cerebral blood flow and brain tissue oxygen. Acta Neurochir (Wien) 2005, 147(1):51-56. discussion 56.

20. Wang L, Zhang Z, Wang Y, Zhang R, Chopp M: Treatment of stroke with erythropoietin enhances neurogenesis and angiogenesis and improves neurological function in rats. Stroke 2004, 35(7):1732-1737.

21. Marti HH, Bernaudin M, Petit E, Bauer C: Neuroprotection and Angiogenesis: Dual Role of Erythropoietin in Brain Ischemia. News Physiol Sci 2000, 15:225-229.

22. Cuzzocrea S, Di Paola R, Mazzon E, Patel NS, Genovese T, Muia C, Crisafulli C, Caputi AP, Thiemermann C: Erythropoietin reduces the development of nonseptic shock induced by zymosan in mice. Crit Care Med 2006, 34(4):1168-1177.

23. Vespa P, Bergsneider M, Hattori N, Wu HM, Huang SC, Martin NA, Glenn TC, McArthur DL, Hovda DA: Metabolic crisis without brain ischemia is common after traumatic brain injury: a combined microdialysis and positron emission tomography study. J Cereb Blood Flow Metab 2005, 25(6):763-774.

24. Corwin HL, Gettinger A, Fabian TC, May A, Pearl RG, Heard S, An R, Bowers PJ, Burton P, Klausner MA, et al: Efficacy and safety of epoetin alfa in critically ill patients. N Engl J Med 2007, 357(10):965-976.

25. Springborg JB, Ma X, Rochat P, Knudsen GM, Amtorp O, Paulson OB, Juhler M, Olsen NV: A single subcutaneous bolus of erythropoietin normalizes cerebral blood flow autoregulation after subarachnoid haemorrhage in rats. Br J Pharmacol 2002, 135(3):823-829.

\section{doi:10.1186/1471-2377-12-32}

Cite this article as: Helbok et al: High dose Erythropoietin increases Brain Tissue Oxygen Tension in Severe Vasospasm after Subarachnoid Hemorrhage. BMC Neurology 2012 12:32.

\section{Submit your next manuscript to BioMed Central and take full advantage of:}

- Convenient online submission

- Thorough peer review

- No space constraints or color figure charges

- Immediate publication on acceptance

- Inclusion in PubMed, CAS, Scopus and Google Scholar

- Research which is freely available for redistribution 